\title{
Agronomic performance and severity of common rust in maize under different nitrogen sources
}

Hélcio Duarte Pereira ${ }^{1}$

Renzo Garcia Von Pinho²

Ivan Vilela Andrade Fiorini ${ }^{3}$

Ewerton Lélys Resende ${ }^{4}$

Felipe Ribeiro Resende 5

Luiz Paulo Miranda Pires ${ }^{6}$

\section{Summary}

Nitrogen is the most required and complex management element in maize crop, promoting the highest responses in crop yield. The objective of this work was to verify the effect of different $\mathrm{N}$ sources on topdressing in minimum tillage and conventional tillage systems on the agronomic performance of the Pioneer 32R22YHR single cross and on the severity of common rust disease. Two experiments were carried out in a randomized block design (DBC) in the 2013/14 crop in minimum tillage and conventional tillage systems. The treatments were: control without nitrogen, ammonium sulfate, urea, ammonium nitrate, a physical mixture of nitrate (70\%) and ammonium sulfate (30\%) and a chemical mixture of these same sources in the same proportion just explained. Nitrogen sources had no significant effect on plant height, ear insertion height, ear prolificacy, grain yield and leaf severity of common rust, regardless of the sowing system. Under conventional tillage, the plants presented higher plant height, ear insertion and grain yield. There was no effect of sowing systems on prolificacy. With the exception of nitrogen free treatment, for all others, the severity of common rust was higher in minimum tillage system.

Keywords: No-till. Zea mays. Puccinia sorghi. Nitrate. Ammonium.

\section{Introduction}

Among the factors that contribute to the low average maize yield in Brazil is the incorrect management of fertilizers, especially nitrogen (MEIRA et al., 2009; OLIVEIRA et al., 2016; VARGAS et al., 2015). Nitrogen ( $N$ ) is a strategic element in maize production and the search for more efficient sources of this nutrient has the potential to strongly impact crop production systems. $\mathrm{N}$ participates in many metabolic processes related to plant defense mechanisms, and can, beyond directly benefit

\footnotetext{
1 Universidade Federal de Lavras (UFLA), mestrado em Fitotecnia. Lavras, Minas Gerais. hhelciopassos@yahoo.com.br Rua Comendador José Esteves, 284, Centro, Lavras Minas Gerais, CEP 37.200-000.

2 UFLA, professor do Departamento de Agricultura UFLA. renzo@dag.ufla.br.

3 Universidade Federal do Mato Grosso (UFMT) Campus Sinop, pesquisador associado. ivanvaf@yahoo.com.br.

4 UFLA, mestrado em Genética. ewertonlr@yahoo.com.br.

5 UFLA, graduando em Agronomia. feliperibeiroresende@gmail.com.

6 UFLA, doutorado em Fitotecnia. luizpaulo_vortex@hotmail.com.
} 
yield, aid in disease tolerance (CHAGAS et al., 2018). N fertilization in maize is one of the main management tools to obtain high yields (MOTA et al., 2015).

$\mathrm{N}$ is the only one among mineral nutrients that can be absorbed by plants in two distinct forms: as $\mathrm{NO}^{-3}$ anion or as $\mathrm{NH}^{4}+$ cation (BELOW, 2002). N is a constituent of many stable compounds, including some inorganic compounds such as ammonium or nitrate salts and other organic compounds such as amino acids and nucleotides. These compounds differ deeply in their chemical properties (BLOOM, 2015).

To balance $\mathrm{N}$ nutritional requirements with environmental availability, plants need to modulate individual $\mathrm{N}$ metabolism steps such as absorption, $\mathrm{NO}^{-3}$ reduction, $\mathrm{NH}^{4+}$ assimilation, and $\mathrm{N}$ recycling (PRINSI; ESPEN, 2015). The dynamics of soil $\mathrm{N}$ is complex due to the numerous interactions with environmental factors. Thus, a better understanding of how is this behavior under prevailin cultivation conditions becomes of special importance to subsidize actions in order to improve the efficiency of $\mathrm{N}$ fertilization in maize crop, required in large amounts. Thus, there is interest in the use of alternative sources that enable the reduction of losses, increasing the efficiency of $\mathrm{N}$ use and, consequently, grain yield (SORATTO et al., 2011). The right choice of $\mathrm{N}$ source for maize fertilization is reflected in the profitability of the production system as a whole, taking into account not only the unit cost of fertilizer, but also the dose and its productive efficiency (SOUZA et al., 2012).

Although it is recognized that nutrition can influence the incidence of plant disease, little progress has been made in managing crop nutrition to improve phytosanitary control (WALTERS; BINGHAM, 2007). $N$ fertilization of the plant can influence the amount and pathogenicity of the fungal spores produced and, consequently, interfere with secondary cycles of disease in the field, as in the case of leaf rusts (ABRO et al., 2013). Among them, the common rust (Puccinia sorghi) has prominence in corn crop due to its wide distribution and damage potential.

Riedeman and Tracy (2010) evaluated 36 important commercial maize cultivars used in the American Corn Belt from 1930 to the present and found a significant increase in resistance levels to this leaf disease $\left(0.05 \%\right.$ year $\left.^{-1}\right)$ at the same time as yield more than quadrupled during the period. Dey et al. (2012), in turn, found estimates of grain yield losses in cultivars susceptible to common rust ranging from 11.75 to $60.53 \%$ in tropical conditions.

Nutrient supply to plants is directly related to their vegetative development and, consequently, to the leaf area available for attack by pathogens. Pegoraro et al. (2001) state that soil fertility level is an important factor for plant predisposition to diseases. In turn, Tomazela et al. (2006) state that balanced mineral nutrition, especially regarding $\mathrm{N}$, can attenuate disease severity. The objective of this work was to verify the effect of different $\mathrm{N}$ sources applied in topdressing, in minimum tillage and conventional tillage systems, on the agronomic performance of Pioneer 32R22YHR single cross and on the severity of common rust disease.

\section{Material and methods}

Two experiments were carried out in Lavras-MG from November 2013 to April 2014, one in conventional tillage and the other in minimum tillage system. The climate on this place is classified as mesothermic, with annual average temperatures of $19.3^{\circ} \mathrm{C}$, annual average precipitation of 1,411 $\mathrm{mm}$, with $70.0 \%$ of this total concentrated from December to March.

The first experiment was carried out in a conventional tillage system in the experimental area of the Department of Agriculture at the campus of the Federal University of Lavras (UFLA), in a dystrophic Red Latosol (LVAd), with clay content of 54.0 dag kg ${ }^{-1}$ and $4.0 \%$ slope (SANTOS, 2013). The 
results obtained with the chemical analysis of this soil $\left(0-20 \mathrm{~cm}\right.$ depth) were: $\mathrm{pH}$ in $\mathrm{H}_{2} \mathrm{O}=5.7$; $\mathrm{P}=$ $11.1 \mathrm{mg} \mathrm{dm}^{-3} ; \mathrm{K}=109.0 \mathrm{mg} \mathrm{dm}^{-3} ; \mathrm{Ca}=39.0 \mathrm{mmolc} \mathrm{dm}^{-3} ; \mathrm{Mg}=12.0 \mathrm{mmolc} \mathrm{dm}^{-3} ; \mathrm{V} \%=57.1$; organic matter $=30.0 \mathrm{~g} \mathrm{~kg}^{-1}, \mathrm{~S}_{-} \mathrm{SO}^{-4}=4.8 \mathrm{mg} \mathrm{dm}^{-3}, \mathrm{Zn}^{2+}=5.5 \mathrm{mg} \mathrm{dm}^{-3}, \mathrm{Mn}^{2+}=14.3 \mathrm{mg} \mathrm{dm}^{-3}$, $\mathrm{Cu}^{2+}=3.0 \mathrm{mg} \mathrm{dm}^{-3}$ and $\mathrm{B}=0.6 \mathrm{mg} \mathrm{dm}^{-3}$.

The second experiment was carried out in the experimental area of the UFLA Department of Agriculture, located in Lavras-MG in a minimum tillage system, on soil classified as Dystrophic Red Yellow Latosol (LVAd), with a clay content of 57.0 dag. $\mathrm{kg}^{-1}$ and slope of $9 \%$. The results obtained with the chemical analysis of the soil at this location (0-20 cm depth) were: $\mathrm{pH}$ in $\mathrm{H}_{2} \mathrm{O}=5.5 ; \mathrm{P}=4.6$ $\mathrm{mg} \mathrm{dm}{ }^{-3} ; \mathrm{K}=72.0 \mathrm{mg} \mathrm{dm}^{-3} ; \mathrm{Ca}=12.0 \mathrm{mmolc} \mathrm{dm}^{-3} ; \mathrm{Mg}=5.0 \mathrm{mmolc} \mathrm{dm}^{-3} ; \mathrm{V} \%=42.5 ;$ organic matter $=25.0 \mathrm{~g} \mathrm{~kg}^{-1}, \mathrm{~S}-S O^{-4}=9.8 \mathrm{mg} \mathrm{dm}^{-3}, \mathrm{Zn}^{2+}=4.3 \mathrm{mg} \mathrm{dm}^{-3}, \mathrm{Mn}^{2+}=9.1 \mathrm{mg} \mathrm{dm}^{-3}, \mathrm{Cu}^{2+}=1.5$ $\mathrm{mg} \mathrm{dm}^{-3}$ and $\mathrm{B}=0.7 \mathrm{mg} \mathrm{dm}^{-3}$. Experimental areas in previous years had been cultivated for more than five years with maize sowing after maize and off season fallow interval.

Different sources of $\mathrm{N}$ applied in topdressing were evaluated when the maize plants had 4 to 6 fully expanded leaves. For all treatments the amount of $\mathrm{N}$ supplied was $120.0 \mathrm{~kg} \mathrm{ha}^{-1}$ aiming at good crop yield and varying the amount of $\mathrm{N}$ source as a function of the element content in each fertilizer. The treatments consisted of a control without $\mathrm{N}$; ammonium sulfate $(21.0 \% \mathrm{~N})$; urea $(45.0 \%$ $\mathrm{N}$ ); ammonium nitrate $(34.0 \% \mathrm{~N})$; physical mixture of $70.0 \%$ and $30.0 \%$ by weight of ammonium nitrate and sulphate respectively, so that the final $\mathrm{N}$ content in the granule mixture was $30.0 \%$ and a chemical mixture of ready-made ammonium nitrate and sulphate, with $30.0 \% \mathrm{~N}$ content. Sowing fertilization was the same for all treatments and consisted of $450.0 \mathrm{~kg} \mathrm{ha}^{-1}$ of the formulated N-P-K 08-24-12. In addition, all treatments received $80.0 \mathrm{~kg}^{-1}$ of $\mathrm{KCl}$ in topdressing, along $\mathrm{N}$ from the evaluated sources, which were applied to the surface as a continuous fillet beside the plants.

The genetically modified maize cultivar Pioneer 32R22YHR was used, an early single cross classified as moderately susceptible to the common rust fungus Puccinia sorghi, with a final population of 65,000 plants ha $^{-1}$ for both experiments. In the minimum tillage system, sowing was performed on $11 / 29 / 2013$ and in the experiment on conventional tillage system on $12 / 7 / 2013$. The areas used to carry out the experiments were desiccated with Roundup-Transorb herbicide 15 days before sowing.

The crop management was commonly performed in the region for good yield potential maize and was similar in the experiments, being performed when necessary. Weed control was carried out at a 5-leaf expanded stage using 3.0 L ha-1 of atrazine mixture and $2.0 \mathrm{~L} \mathrm{ha}^{-1}$ of Roundup at 30 days after sowing. For insect control the insecticide Match was applied at a dosage of $500.0 \mathrm{ml} \mathrm{ha}^{-1}$ at 50 days after maize emergence. The experimental design was randomized blocks (DBC) with five replications, with a draw for each experiment. The experimental plot consisted of six $0.8 \mathrm{~m}$ spaced rows, $5 \mathrm{~m}$ long, for the no-till experiment and $4 \mathrm{~m}$ long for the conventional tillage experiment. The two central lines were considered useful area of the plot.

The following traits were evaluated: a) Plant height $(\mathrm{m})$ - measured in four plants in the useful area of the plot before harvest, from soil level to the insertion of the flag leaf; b) Ear insertion height (m) - measured in four plants in the useful area of the plot before harvest, considering the insertion height of the first ear; c) Ear prolificacy - total ears present in the useful area of the plot divided by the total plants in that area; d) Grain yield ( $\mathrm{kg} \mathrm{ha}^{-1}$ ) - obtained based on the total grain in the useful area, adjusted to the moisture of $13.0 \%$ on a wet basis; e) Common rust severity - area under the disease progress curve (AACPD) according to the methodology of Campbell and Madden (1990).

To evaluate the severity of common rust on plants, a diagrammatic grade scale was used (AGROCERES, 1996) by analyzing four random plants in the plot in each evaluation, for a total of 5 
evaluations for each experiment. The plants were subjected to the natural occurrence of rust due to disease-favorable weather conditions and evaluations began with the first symptoms of the disease in the field. For the experiment carried out under conventional tillage the evaluations occurred at 58, $69,80,90$ and 99 days after sowing. For the minimum tillage system experiment the dates were at 67, 78, 8798 and 103 days after sowing.

The data were subjected to the joint analysis of variance of the experiments, with application of the $\mathrm{F}$ test, and the means compared by Tukey test at 5.0\% probability, using the $\mathrm{R}$ statistical software (R core Team, 2015).

\section{Results and discussion}

Table 1 presents the precipitation and average temperatures of the region, by decay (ten days periods), ranging from the beginning of the experiments until the female flowering phase of maize (R1) that occurred on 01/30/14 for the experiment in minimum tillage system and on 02/02/14 for the experiment in conventional tillage system. Note the irregularity of precipitation during the development of the maize and the tendency of rising temperatures in the considered period. This allows us to state that this was an atypical year in relation to the water regime, considering the long summer periods that occurred.

Table 1 - Climatological data of the region of the experiments in the considered period. UFLA, Lavras-MG.

\begin{tabular}{cccc}
\hline Period & Decay & Precipitation $(\mathrm{mm})$ & Average temperature $\left({ }^{\circ} \mathrm{C}\right)$ \\
\hline $29 / 11-09 / 12$ & $1^{\circ}$ & 89.4 & 23.03 \\
$09 / 12-19 / 12$ & $2^{\circ}$ & 32 & 21.93 \\
$19 / 12-29 / 12$ & $3^{\circ}$ & 53.6 & 22.86 \\
$29 / 12-08 / 01$ & $4^{\circ}$ & 2.8 & 23.91 \\
$08 / 01-18 / 01$ & $5^{\circ}$ & 86.9 & 24.07 \\
$18 / 01-28 / 01$ & $6^{\circ}$ & 161.4 & 23.58 \\
$28 / 01-07 / 02$ & $7^{\circ}$ & 0 & 24.75 \\
$07 / 02-17 / 02$ & $8^{\circ}$ & 30.5 & 23.08 \\
\hline
\end{tabular}

Source: Elaboration by authors (2015).

It can be observed from the results of the joint analysis of variance that for none of the traits evaluated there was a significant effect of the $N$ sources studied (TABLE 2). Concerning the tillage systems only for ear prolificacy the effect was not significant, which shows significant differences between the conventional and minimum tillage systems for plant height, ear insertion height, grain yield and the severity of common rust. The validity of the joint analysis is also verified as a function of the relation between the residual mean squares of the individual analyzes. The interaction between these factors occurred only for the common rust severity. Experimental precision is classified as medium to high considering the values of the coefficient of variation (CV). 
Table 2 - Summary of joint analysis of variance for plant height (AP), ear insertion height (AIE), ear prolificacy (PROL), grain yield (PROD), and common rust severity (SF) in maize.

\begin{tabular}{lcccccc}
\hline \multirow{2}{*}{ Sources } & \multirow{2}{*}{ DF } & \multicolumn{5}{c}{ Mean Squares $^{(1)}$} \\
\cline { 3 - 7 } & & AP & AIE & PROL & PROD & SF \\
\hline Tillage system (T) & 1 & $0.91452^{*}$ & $0.30495^{*}$ & $0.0000408^{\text {ns }}$ & $16,736,356^{*}$ & $5,094.5^{*}$ \\
Sources of Nitrogen (S) & 5 & $0.01182^{\text {ns }}$ & $0.001405^{\text {ns }}$ & $0.0047333^{\text {ns }}$ & $1,478,277^{\text {ns }}$ & $34.1^{\text {ns }}$ \\
$\mathrm{T}^{*} \mathrm{~S}$ & 5 & $0.00725^{\text {ns }}$ & $0.001486^{\text {ns }}$ & $0.0064549^{\text {ns }}$ & $2,003,265^{\text {ns }}$ & $249.8^{*}$ \\
Blocks/T & 8 & 0.03554 & 0.021003 & 0.0029179 & $12,574,369$ & 124.4 \\
Residue & 40 & 0.0114 & 0.006973 & 0.0047995 & $2,418,985$ & 83.5 \\
\hline CV (\%) & & 4.14 & 6.78 & 7.25 & 17.00 & 9.40 \\
\hline Relation between residual MS & & 1.51 & 1.62 & 1.06 & 4.01 & 2.67 \\
\hline
\end{tabular}

ns and * - not significant and significant at $5 \%$ by the $F$ test, respectively.

Source: Elaboration by authors (2015).

Carmo et al. (2012) also found no effect of $\mathrm{N}$ sources on sweet corn yield and development, evaluating urea and ammonium sulfate as sources of $\mathrm{N}$ supply. Similar result was found by Meira et al. (2009) with the cultivation of irrigated grain corn. Also evaluating $\mathrm{N}$ fertilization in maize on topdressing, Mota et al. (2015) found no differentiated effect on yield from the following sources: ammonium nitrate, common urea, urea with urease enzyme inhibitor and urea with ammonium nitrification inhibitor, in two years of evaluation. Results consistent with those found here were also reported by Schiavinatti et al. (2011) for plant height and main ear insertion, in two years of testing three sources of $\mathrm{N}$. For grain yield only in one of the years, they found disadvantage of urea as source of N. On the other hand, Galindo et al. (2016) evaluated urea and urease inhibitor urea, associated or not with Azospirillum brasilense inoculation, in maize cultivated in minimum tillage system and did not find any effect of the evaluated sources on grain yield and leaf macro and micronutrient contents.

Although several studies did not report a differentiated effect between N sources, Sugiharto and Sugiyama (1992) found that when plants received $N$ ammonium the total and messenger RNA levels of photosynthetic enzyme in C4 plants, phosphoenolpyruvate carboxylase (PEPcase), approximately twice compared to the plants receiving nitrate as a source of $\mathrm{N}$, as well as the levels of amino acid Glutamine. However, these authors did not evaluate these effects until the end of the plant cycle. In any case, this suggests that there may be compensation for slower nitrate metabolism by maize plants throughout the cycle, so that the effects do not persist to physiological maturity when expressing traits such as grain yield and vegetative development. The results of this work, evaluating traits of vegetative development at the end of the maize cycle and also the yield do not prove any metabolic disadvantage of nitrate on ammonium.

Investigating the effects of $\mathrm{N}$ sources based on nitrate and ammonium, supplied in the vegetative phase, Prinsi and Espen (2015) verified several different physiological effects on maize plants. The overall carbon and nitrogen balance was altered as a function of the source, such as sucrose and amino acid contents, differently in roots, xylem sap and leaf tissues. Simultaneous supply of both sources yielded results suggesting a synergistic effect on plant metabolism. Thus, the authors conclude that maize plants need to adapt physiologically as a function of the $\mathrm{N}$ source present in the environment. Such synergistic effect of $\mathrm{N}$ sources did not translate into higher yield or vegetative development in 
the present work, because among the tested sources there were fertilizers formed by mixture of ammonium sulfate and ammonium nitrate that did not surpass these same sources used alone.

By means of yield it is possible to verify that even the treatment without $\mathrm{N}$ did not differ from the other treatments (TABLE 3). This suggests favorable conditions for the crop in both experiments, as it is known that responses to $\mathrm{N}$ in maize are generally very pronounced and severe reductions are expected in its absence (MEIRA et al., 2009).

Table 3 - Average values for the traits plant height (AP), ear insertion height (AIE), ear prolificacy (PROL) and grain yield (PROD) of maize as a function of different sources of $\mathrm{N}$.

\begin{tabular}{lcccc}
\hline \multicolumn{1}{c}{ Sources of Nitrogen } & AP $(\mathrm{m})$ & AIE $(\mathrm{m})$ & PROL & PROD $\left(\mathbf{k g ~ h a}^{-1}\right)$ \\
\hline No nitrogen & 2.56 & 1.24 & 0.93 & $8,601.47$ \\
Ammonium sulfate (SA) & 2.56 & 1.22 & 0.95 & $9,575.54$ \\
Urea & 2.63 & 1.23 & 0.99 & $9,512.15$ \\
Ammonium nitrate (NA) & 2.56 & 1.22 & 0.96 & $9,315.86$ \\
Physical mixture (NA + AS) & 2.62 & 1.25 & 0.93 & $8,856.54$ \\
Chemical mixture (NA + AS) & 2.55 & 1.23 & 0.97 & $9,038.69$ \\
\hline F test & $1.04_{\text {ns }}$ & $0.202_{\text {ns }}$ & $0.986_{\text {ns }}$ & $0.611_{\text {ns }}$ \\
\hline
\end{tabular}

Source: Elaboration by authors (2015).

Mota et al. (2015) evaluating sources and doses of $\mathrm{N}$ in topdressing also found high yield for the treatment without $\mathrm{N}$ and attributed this fact to a high availability of $\mathrm{N}$ in the soil. Thus, favorable environmental conditions may have contributed to the lack of effect of $\mathrm{N}$ sources, as they make the differences between them small. Lange et al. (2008) also found no response in yield to $\mathrm{N}$ fertilization in maize and attribute this to the differentiated favorable conditions of the study, such as history of the area, as it must have occurred in the present work. Maize response to $\mathrm{N}$ fertilizer is affected by climatic and soil factors, so response curves can vary greatly between different sites. Thus, in a fertile soil with a high residual $\mathrm{N}$ supply, nitrogen fertilizers may have no effect or even decrease yields (BELOW, 2002). Amanullah (2014) illustrates well the variable response in harvest index and efficiency of use by maize plants to nitrogen fertilizers as a function of the source used and also the doses, year and cultivar. The work of Soratto et al. (2011) corroborate with the results presented here for the effect of $\mathrm{N}$ sources on maize yield. These authors did not find any difference in crop performance as a function of the $\mathrm{N}$ source used for topdressing. However, unlike what occurred in the present study, differential response in relation to the absence of the nutrient was verified, even using lower doses.

It was noted that the conditions in the conventional tillage system were more favorable to maize due to the better yield and vegetative development (FIGURE 1). The area managed under the minimum tillage system, although with a history of monoculture of maize, was not an area under consolidated no-tillage system with crop rotations, due to soil surface mulching conditions and crop management, which may have harmed the culture. It is known that the soil tillage system can influence $\mathrm{N}$ availability and its use by the crop due to the alteration of the physical properties, as well as its chemical and biotic components (BELOW, 2002). 
Figure 1 - Average values for the traits plant height (AP), ear insertion height (AIE), ear prolificacy (PROL) and grain yield (PROD) of maize as a function of sowing/tillage system, conventional tillage (PC) and minimum tillage (PD).

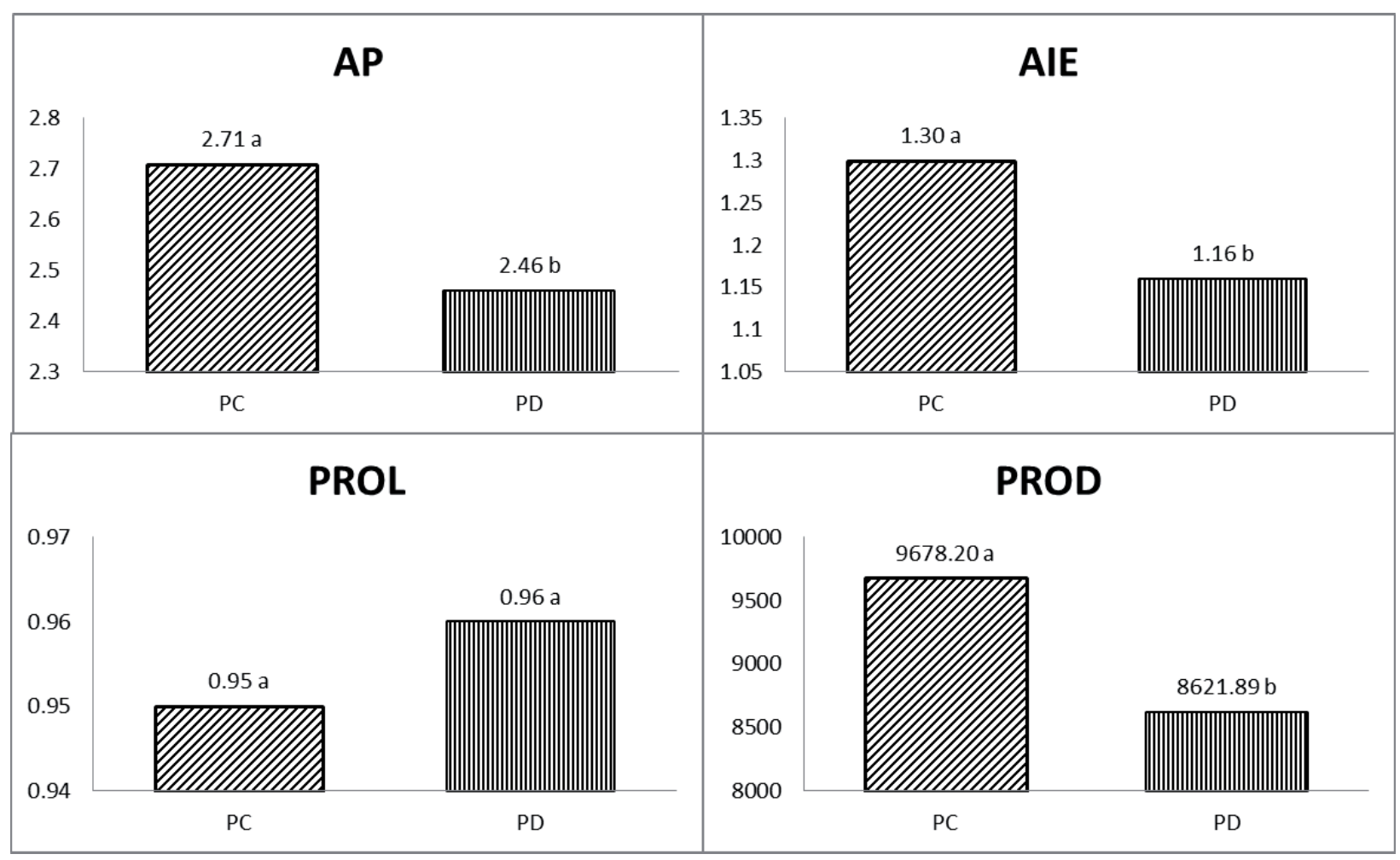

Source: Elaboration by authors (2015).

Lange et al. (2008) state that in no-tillage system the nutrient dynamics as well as their horizontal and vertical variability are different. Oliveira et al. (2016) point out that studies with $\mathrm{N}$ involve different sowing/cultivation systems, climatic and soil conditions and, therefore, generalizations about $\mathrm{N}$ management do not fit well. For the unfolding of sowing/tillage systems within each source of $\mathrm{N}$ (TABLE 4), it is observed that the severity of common rust was higher under minimum tillage system, except for treatment without N. Maize remains in the area under minimum tillage and it should not be the cause of the higher severity of rust, since it is a biotrophic fungus, therefore, unaffected by crop residues as a possible source of inoculum.

Table 4 - Unfolding of nitrogen source interaction and crop tillage systems for common rust severity, as measured by area below the disease progress curve.

\begin{tabular}{lcc}
\hline Sources of $\mathbf{N}$ & Conventional tillage & Minimum tillage \\
\hline No nitrogen & 95.00 a A ${ }^{(1)}$ & 93.98 a A \\
Ammonium sulfate (SA) & 86.28 a B & 107.40 a A \\
Urea & 86.33 a B & 109.30 a A \\
Ammonium nitrate (NA) & 85.68 a B & 109.98 a A \\
Physical mixture (SA + NA) & 91.45 a B & 108.65 a A \\
Chemical mixture (SA + NA) & 83.38 a B & 109.38 a A \\
\hline
\end{tabular}

(1) In each column, means followed by the same lower case and, in each row, higher case, do not differ at $5 \%$ probability by the Tukey test.

Source: Elaboration by authors (2015). 
Prior to the installation of the experiments, there were no tiguera maize plants in the areas used under minimum and conventional tillage system, which also contributes to low inoculum source. The particular microclimate created in the area under minimum tillage system and the fact that there are other areas with maize nearby are pertinent factors to explain the higher severity of the disease in this experiment. It is intriguing that only for treatment without $\mathrm{N}$ there was no difference in disease severity between the two tillage systems. It could be thought that in this situation the plants had less vegetative development giving rise less leaf area for possible fungal attack, not allowing to verify the difference between the tillage systems. However, just in the minimum tillage system that the crop presented the lowest vegetative development, considering the traits of plant height and ear insertion, yet presenting higher disease severity for all other treatments. Thus, these results do not allow a direct association between vegetative development and severity of common rust in maize, as addressed by other studies.

Gomes et al. (2007) studying the management of $\mathrm{N}$ fertilization in maize also found no effect of $\mathrm{N}$ on disease severity, although based on the premise that treatments that promote greater vegetative development would have greater severity of leaf diseases, consequently. On the other hand, Pegoraro et al. (2001) attribute the non-occurrence of unbalanced nutrition to the fact that they did not verify the effect of different levels of fertilization on phaeosphaeria leaf spot severity in maize. Contrary to what was found here, Tomazela et al. (2006) found that treatments that received higher amounts of $N$ had higher leaf area index and, simultaneously, higher incidence of tropical rust. Santos et al. (2014) attribute the higher severity of rice blast at higher $\mathrm{N}$ rates to the increase in leaf area and number of panicles in response to the large nutrient supply.

It is a fact that plant responses to pathogens vary from crop to crop depending on the environmental conditions, which are particular to each situation. The work of Santos et al. (2013) illustrates this case. The authors found an effect of $\mathrm{N}$ doses on the severity of common rust in maize only in one of the years of study, with no record of its occurrence in another year of research. Thus, there may have been insufficient pressure of this disease in the year of conducting the experiments of the present work, in such a way as to not allow verifying the effect of $\mathrm{N}$ sources.

\section{Conclusions}

The sources of $\mathrm{N}$, at a dose of $120.0 \mathrm{~kg} \mathrm{ha}^{-1}$ applied between V4 and V6 stage, evaluated in this work do not influence the agronomic performance and severity caused by common rust in maize.

The conventional tillage system provides higher plant height, ear insertion and grain yield compared to the minimum tillage system for the conditions evaluated in this work.

The severity of common rust in maize is higher under minimum tillage system for all nitrogen sources studied, except for the absence of nitrogen. 


\section{Desempenho agronômico e severidade de ferrugem comum em milho sob diferentes fontes de nitrogênio}

\section{Resumo}

O nitrogênio é o elemento mais requerido e de manejo mais complexo na cultura do milho, promovendo as maiores respostas na produtividade da cultura. Objetivou-se com este trabalho verificar o efeito de diferentes fontes de $\mathrm{N}$ em cobertura, em sistemas de semeadura em cultivo mínimo e semeadura em preparo convencional do solo, no desempenho agronômico do híbrido simples de milho Pioneer 32R22YHR e na severidade da doença ferrugem comum. Foram implantados dois experimentos em delineamento blocos ao acaso (DBC) na safra 2013/14 em sistemas de semeadura em cultivo mínimo e semeadura em preparo convencional do solo. Os tratamentos foram: testemunha sem N, sulfato de amônio, ureia, nitrato de amônio, uma mistura física de nitrato (70\%) e sulfato de amônio (30\%) e uma mistura química dessas mesmas fontes na mesma proporção. As fontes de $\mathrm{N}$ não tiveram efeito significativo na altura de planta, altura de inserção de espiga, prolificidade, produtividade de grãos e severidade foliar de ferrugem comum, independentemente do sistema de semeadura. Sob sistema de semeadura em preparo convencional do solo, as plantas apresentaram maior altura de planta, inserção de espiga e produtividade de grãos. Não houve efeito dos sistemas de semeadura para a prolificidade. Com exceção do tratamento sem N, para todos os demais, a severidade de ferrugem comum foi maior em sistema de semeadura em cultivo mínimo.

Palavras-chave: Plantio direto. Zea mays. Puccinia sorghi. Nitrato. Amônio.

\section{Referências}

ABRO, M. A.; LECOMPTE, F.; BRYONE, F.; NICOT, P. C. Nitrogen fertilization of the host plant influences production and pathogenicity of Botrytis cinerea secondary inoculum. Phytopathology, v. 103, n. 3, p. 261-267, 2013. DOI: 10.1094/PHYTO-08-12-0189-R

AGROCERES. Guia agroceres de sanidade. 2 ed. São Paulo: Sementes Agroceres S/A, 1996. 72 p.

AMANULLAH. Source and rate of nitrogen application influence agronomic N-use efficiency and harvest index in maize (Zea mays L) genotypes. Maydica, v. 59, n. 1-4, p. 81-90, 2014.

BELOW, F. E. Fisiologia, nutrição e adubação nitrogenada do milho. Informações Agronômicas, Piracicaba, n. 99, p. 7-12, 2002.

BLOOM, A. J. The increasing importance of distinguishing among plant nitrogen sources. Current opinion in plant biology, v. 25, p. 10-16, 2015. DOI: 10.1016/j.pbi.2015.03.002

CAMPBELL, C. L.; MADDEN, L. V. Introduction to Plant Disease Epidemiology. New York City: John Wiley \& Sons, 1990. 
CARMO, M. S.; CRUZ, S. C. S.; SOUZA, E. J. de; CAMPO, L. F. C.; MACHADO, C. G. Doses e fontes de Nitrogênio no desenvolvimento e produtividade da cultura de milho doce (Zea mays convar. saccharata var. rugosa). Bioscience Journal, Uberlândia, v. 28, n. 1, p. 223-231, 2012.

CHAGAS, J. F. R.; SANTOS, G. R.; COSTA, R. V.; ALVES, J. F.; NASCIMENTO, I. R. Adubação nitrogenada na severidade de doenças foliares, produtividade e respostas bioquímicas em híbridos de milho. Revista Brasileira de Milho e Sorgo, Sete Lagoas, v. 17, n. 1, p. 1-14, 2018. DOI: http://dx.doi. org/10.18512/1980-6477/rbms.v17n1p1-14

DEY, U.; HARLAPUR, S. I.; DHUTRAJ, D. N.; SURYAWANSHI, A. P.; BADGUJAR, S. L.; JAGTAP, G. P.; KULDHAR, D. P. Spatiotemporal yield loss assessment in corn due to common rust caused by Puccinia sorghi Schw. African Journal of Agricultural Research, v. 7, n. 37, p. 5265-5269, 2012. DOI: $10.5897 /$ AJAR12.1103

GALINDO, F. S.; TEIXEIRA FILHO, M. C. M.; BUZETTI, S.; SANTINI, J. M. K.; ALVES, C. J.; NOGUEIRA, L. M.; LUDKIEWICZ, M. G. Z.; ANDREOTTI, M.; BELLOTTE, J. L. M. Corn Yield and Foliar Diagnosis Affected by Nitrogen Fertilization and Inoculation with Azospirillum brasilense. Revista Brasileira de Ciência do Solo, Viçosa, v. 40, 2016. DOI: 10.1590/18069657rbcs20150364

GARCIA, P. L.; GONZÁLEZ-VILLALBA, H. A.; SERMARINI, R. A.; TRIVELIN, P. C. O. Nitrogen use efficiency and nutrient partitioning in maize as affected by blends of controlled-release and conventional urea. Archives of Agronomy and Soil Science, v. 64, n. 14, p. 1944-1962, 2018. DOI: 10.1080/03650340.2018.1469746

GOMES, R. F.; SILVA, A. G.; ASSIS, R. L.; PIRES, F. R. Efeito de doses e da época de aplicação de nitrogênio nos caracteres agronômicos da cultura do milho sob semeadura direta. Revista Brasileira de Ciência do Solo, Viçosa, v. 31, p. 931-938, 2007. DOI: 10.1590/S0100-06832007000500010

LANGE, A.; CABEZAS, W. A. R. L.; TRIVELIN, P. C. O. Recuperação do nitrogênio das fontes sulfato e nitrato de amônio pelo milho em sistema semeadura direta. Pesquisa Agropecuária Brasileira, Brasília, v. 43, n.1, p. 123-130, 2008. DOI: 10.1590/S0100-204X2008000100016

MEIRA, F. A.; BUZETTI, S.; ANDREOTTI, M.; ARF, A.; SÁ, M. E.; ANDRADE, J. A. C. Fontes e épocas de aplicação do nitrogênio na cultura do milho irrigado. Semina: Ciências Agrárias, Londrina, v. 30, n. 2, p. 275-284, 2009. DOI: 10.5433/1679-0359.2009v30n2p275

MOTA, M. R.; SANGOI, L.; SCHENATTO, D. E.; GIORDANI, W.; BONIATTI, C. M.; DALL'IGNA, L. Fontes estabilizadas de nitrogênio como alternativa para aumentar o rendimento de grãos e a eficiência de uso do nitrogênio pelo milho. Revista Brasileira de Ciência do Solo, Viçosa, 39, n. 2, p. 512-522, 2015. DOI: 10.1590/01000683rbcs20140308

OLIVEIRA, F. C.; SOUSA NETTO, M.; ARAUJO, L. S.; ALMEIDA, A. C. S.; SILVEIRA, P. M.; CUNHA, P. C. R. Corn development and production in function of sources of nitrogen fertilizers and doses. Revista Caatinga, Mossoró, v. 29, n. 4, p. 812-821, 2016. DOI: 10.1590/1983-21252016v29n405rc 
PEGORARO, D. G.; VACARO, E.; NUSS, C. N.; SOGLIO, F. K. D.; SERENO, M. J. C. M.; BARBOSA NETO, J. F. Efeito de época de semeadura e adubação na mancha-foliar de Phaeosphaeria em miIho. Pesquisa Agropecuária Brasileira, Brasília, v. 36, n. 8, p. 1037-1042, 2001. DOI: 10.1590/ S0100-204X2001000800005

PEREIRA, O. A. P. Doenças do milho. In: KIMATI, H.; AMORIM, L.; REZENDE, J.A.M.; BERGAMIN FILHO, A.; CAMARGO, L.E.A. ed. Manual de Fitopatologia. Volume 2. Doenças das Plantas Cultivadas. 3. ed. São Paulo: Agronômica Ceres, 1997. v. 2. p. 500-516.

PRINSI, B.; ESPEN, L. Mineral nitrogen sources differently affect root glutamine synthetase isoforms and amino acid balance among organs in maize. BMC plant biology, v. 15, n. 1, p. 1, 2015. DOI: 10.1186/s12870-015-0482-9

R CORE TEAM (2015). R: A language and environment for statistical computing. R Foundation for Statistical Computing, Vienna, Austria. URL https://www.R-project.org/.

RIEDEMAN, E. S.; TRACY, W. F. Vegetative phase change characteristics and resistance to common rust of corn cultivars developed in different eras. Crop science, v. 50, n. 1, p. 87-92, 2010. DOI: 10.2135/cropsci2008.11.0656

SANTOS, G. R.; GAMA, F. R.; GONÇALVES, C. G.; RODRIGUES, A. C.; LEÃO, E. U.; CARDON, C. H.; BONIFÁCIO, A. Severidade de doenças foliares e produtividade de genótipos de milho em resposta à adubação nitrogenada. Revista Ceres, Viçosa, v. 60, n. 4, p. 505-513, 2013. DOI: 10.1590/S0034737X2013000400009

SANTOS, G. R.; CASTRO NETO, M. D.; RODRIGUES, A. C.; BONIFACIO, A.; KORNDORFER, G. H. Fertilização silicatada e nitrogenada no controle da brusone do arroz em sistema irrigado. Revista Caatinga, Mossoró, v. 27, n. 4, p. 103-108, 2014.

SANTOS, H. G. dos; JACOMINE, P. K. T.; ANJOS, L. H. C. dos; OLIVEIRA, V. A. de; LUMBRERAS, J. F.; COELHO, M. R.; ALMEIDA, J. A. de; CUNHA, T. J. F.; OLIVEIRA, J. B. de. Sistema brasileiro de classificação de solos. 3. ed. rev. e ampl. Brasília, DF: Embrapa, 2013. 353 p.

SCHIAVINATTI, A. F.; ANDREOTTI, M.; BENETT, C. G. S.; PARIZ, C. M.; LODO, B. N.; BUZETTI, S. Influência de fontes e modos de aplicação de nitrogênio nos componentes da produção e produtividade do milho irrigado no Cerrado. Bragantia, Campinas, v. 70, n. 4, p. 925-930, 2011. DOI: 10.1590/S0006-87052011000400027

SORATTO, R. P.; SILVA, A. H.; CARDOSO, S. M.; MENDONÇA, C. G. Doses e fontes alternativas de Nitrogênio no milho sob semeadura direta em solo arenoso. Ciência e Agrotecnologia, Lavras, v. 35, n 1, p. 62-70, 2011. DOI: 10.1590/S1413-70542011000100007

SOUZA, J. A.; BUZETTI, S; TARSITANO, M. A. A.; VALDERRAMA, M. Lucratividade do milho em razão das fontes, doses e épocas de aplicação de nitrogênio. Revista Ceres, Viçosa, v. 59, n. 3, p. 321-329, 2012. DOI: 10.1590/S0034-737X2012000300005 
SUGIHARTO, B.; SUGIYAMA, T. Effects of Nitrate and Ammonium on Gene Expression of Phosphoenolpyruvate Carboxylase and Nitrogen Metabolism in Maize Leaf Tissue during Recovery from Nitrogen Stress. Plant Physiology, v. 98, n. 4, p. 1403-1408, 1992. DOI: 10.1104/pp.98.4.1403

TOMAZELA, A. L.; FAVARIN, J. L.; FANCELLI, A. L.; MARTIN, T. N.; DOURADO NETO, D.; REIS, A. R. Doses de Nitrogênio e fontes de Cu e Mn suplementar sobre a severidade da ferrugem e atributos morfológicos do milho. Revista Brasileira de Milho e Sorgo, Sete Lagoas, v. 5, n. 2, p. 192-201, 2006. DOI: 10.18512/1980-6477/rbms.v5n2p192-201

VARGAS, V. P.; SANGOI, L.; ERNANI, P. R.; PICOLI, G. J.; CANTARELLA, H. Maize Leaf Phytotoxicity and Grain Yield are Affected by Nitrogen Source and Application Method. Agronomy Journal, Madison, v. 107, n. 2, p. 671-679, 2015. DOI: 10.2134/agronj14.0121

WALTERS, D. R.; BINGHAM, I. J. Influence of nutrition on disease development caused by fungal pathogens: implications for plant disease control. Annals of Applied Biology, v. 151, p. 307-324, 2007. DOI: 10.1111/j.1744-7348.2007.00176.x

Received: January 28, 2019

Accepted: April 8, 2019 